\title{
Sinusoidal pattern: a key to a rare case of fetal anaemia
}

\author{
Inês Sá 미 , Mário Moura
}

Department of Gynaecology and Obstetrics, Centro Hospitalar de Trás-os-montes e Alto Douro EPE, Vila Real, Portugal

\section{Correspondence to \\ Inês Sá; \\ ines.palas.sa@gmail.com}

Accepted 22 February 2021

\section{DESCRIPTION}

A 35-year-old healthy pregnant woman, A+ bloodtype, with a history of one vaginal childbirth appeared at the emergency department for reduced fetal movements (RFM). She was 37-week pregnant and no major complications were described during her pregnancy. She had negative indirect Coombs test. She had normal uterine tone, with no blood or amniotic fluid loss. On the ultrasound examination, fetal heart rate and amniotic fluid volume were normal, but there were no active fetal movements. The cardiotocography (CTG) examination displayed a low variability tracing with sinusoidal pattern with no uterine contractility (figure 1). Emergent caesarean section was performed, assuming fetal distress. The newborn weighed $2665 \mathrm{~g}$ and the Apgar score at birth was 0/3/4. Umbilical cord blood gas analysis did not show acute hypoxia or metabolic acidosis $\left(\mathrm{pH} 7.31 ; \mathrm{HCO}_{3-} 20.1 \mathrm{mmol} / \mathrm{L}\right.$; base excess $5,3 \mathrm{mmol} / \mathrm{L} ; \mathrm{pCO}_{2} 40 \mathrm{mmHg} ; \mathrm{pO}_{2} 53 \mathrm{mmHg}$; lactate $6.7 \mathrm{mmol} / \mathrm{L}$ and undetectable haemoglobin $(\mathrm{Hb}))$. By posterior analyses, the newborn was diagnosed with severe anaemia $(\mathrm{Hb}: 4.8 \mathrm{~g} / \mathrm{dL})$, and was transferred to the neonatal intensive care unit. Fetomaternal haemorrhage (FMH) was confirmed by flow cytometry, which estimated $237.7 \mathrm{~mL}$ of fetal blood in maternal blood. Anatomopathological examination of the placenta revealed no changes.

Spontaneous massive FMH is a rare complication that can occur at any time during pregnancy. ${ }^{1}$ It represents a life-threatening condition for the fetus, as it could be responsible for acute fetal anaemia and intrauterine death. Several studies have suggested that FMH could only be revealed by RFM. In women with RFM in the third trimester of pregnancy, it is mandatory to perform a non-stress test/CTG. ${ }^{2}$ According to National Institute of Child Health and Human Development, and concerning CTG, category III fetal heart

\section{Learning points}

- Massive fetomaternal haemorrhage could be asymptomatic. In the antepartum period, decreased or absent fetal movement is the most common presenting symptom.

- Sinusoidal pattern is exceedingly rare and thus intervention has not been studied in a systematic way.

- The sinusoidal pattern is associated with severe fetal anaemia, although the pathophysiologic mechanism has not been definitively proven. Emergent delivery is indicated if resuscitative measures do not improve the pattern.

rate (FHR) pattern is associated with an increased likelihood of severe hypoxia and metabolic acidemia. Sinusoidal pattern is considered a category III FHR pattern. Many studies have shown the association between sinusoidal pattern (III) and fetal anaemia. ${ }^{12}$

Although many suspicious signs, severe FMH can only be diagnosed by the presence of fetal erythrocytes in the maternal circulation. It is consensual that FMH $\geq 20 \%$ of fetal blood volume or $10-150 \mathrm{~mL}$ of fetal blood in maternal circulation could be considered massive $\mathrm{FMH}^{23}$ There are two major forms to estimate the volume of fetal blood lost in an FMH. The Kleihauer-Betke (KB) test is inexpensive and requires no special equipment. Anti-HbF flow cytometry is an automated test unaffected by maternal levels of fetal $\mathrm{Hb}$ or by fetal levels of $\mathrm{Hb} \mathrm{A}$. Comparative analysis of flow cytometry and the KB test has shown that flow cytometry is more accurate, more reproducible and less labour intensive. ${ }^{23}$
Check for updates

(c) BMJ Publishing Group Limited 2021. No commercial re-use. See rights and permissions. Published by BMJ.

To cite: Sá I, Moura M. BMJ Case Rep 2021;14:e241312. doi:10.1136/bcr-2020241312

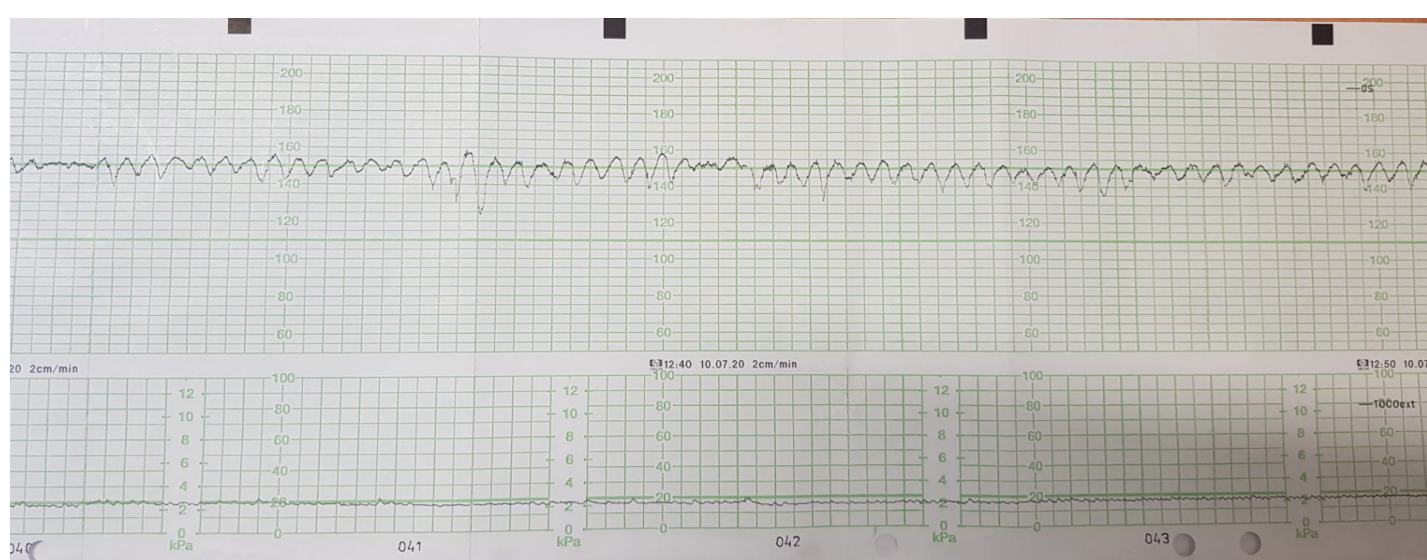

Figure 1 Cardiotocographic tracing showing sinusoidal pattern and the absence of uterine contractions. 
This case, although rare, is quite illustrative of FMH: our patient had RFM as well as category III FHR pattern in non-stress test/CTG (sinusoidal pattern). The newborn had severe anaemia and flow cytometry estimated $237.7 \mathrm{~mL}$ of fetal blood in maternal circulation, which allow us to concluded that was a case of massive FMH. Both the recognition of non-reassuring CTG pattern and the timely intervention were the key to a favourable outcome.

\section{Acknowledgements The authors thank the patient for the consent for} publication.

Contributors The authors IS and MM testified the reported case, ensured the acquisition of clinical data, discussed the diagnosis and prepared the manuscript.

Funding The authors have not declared a specific grant for this research from any funding agency in the public, commercial or not-for-profit sectors.
Competing interests None declared.

Patient consent for publication Obtained.

Provenance and peer review Not commissioned; externally peer reviewed.

\section{ORCID iD}

Inês Sá http://orcid.org/0000-0002-3843-8783

\section{REFERENCES}

1 Modanlou HD, Murata Y. Sinusoidal heart rate pattern: reappraisal of its definition and clinical significance. J Obstet Gynaecol Res 2004:30:169-80.

2 Athiel Y, Maisonneuve E, Bléas $C$, et al. Reduced fetal movement during pregnancy: is the Kleihauer-Betke test really useful? I Gynecol Obstet Hum Reprod 2020:101748.

3 Stefanovic V. Fetomaternal hemorrhage complicated pregnancy: risks, identification, and management. Curr Opin Obstet Gynecol 2016;28:86.

Copyright 2021 BMJ Publishing Group. All rights reserved. For permission to reuse any of this content visit

https://www.bmj.com/company/products-services/rights-and-licensing/permissions/

BMJ Case Report Fellows may re-use this article for personal use and teaching without any further permission.

Become a Fellow of BMJ Case Reports today and you can:

- Submit as many cases as you like

- Enjoy fast sympathetic peer review and rapid publication of accepted articles

- Access all the published articles

- Re-use any of the published material for personal use and teaching without further permission

\section{Customer Service}

If you have any further queries about your subscription, please contact our customer services team on +44 (0) 2071111105 or via email at support@bmj.com.

Visit casereports.bmj.com for more articles like this and to become a Fellow 